\title{
7 \\ Preserving Health and Race in the Tropics
}

\begin{abstract}
At present it is a contest between racial debility and modern science. In places where the racial debility is far advanced, one sees the writing on the wall, though those concerned in the tragedy are not aware of it. But in the case of those who are not too far gone science will win in the long run. Some of the best brains in the world are at work on the matter, and the inhabitants of the Pacific will reap the result ... It is only a matter of time before science will overcome the inertia at the fringes of civilisation and the abuses and mistakes of the past are replaced by the benefits that the white man's knowledge can and should bring to his brother of the stone age. ${ }^{1}$
\end{abstract}

M Kathleen Woodburn published this evaluation of the Pacific Islands based on her experience living on a farm in Erromango (in the New Hebrides) with her son in the 1930s. From her perspective on 'the fringes of civilisation', this inquisitive traveller blended personal narrative and scientific observations-a common technique in Australian travel writing. Pseudo-scientific practice was popular among Australian travellers, both amateur and professional, and scientific language provided an authoritative legitimacy to ordinary tourist impressions. It also formed part of a discourse from which Australian travellers drew when confronted with the reality of human difference. This extensive and racialised discourse had developed throughout 200 years of European exploration and travel in the Pacific. By the 1900s, a racial lexicon had permeated Australian travel writing that informed expectations, predetermined encounters and

1 Woodburn, Backwash of Empire, 223. 
shaped reflections. The taxonomy of race as it was used in the twentieth century was sanctioned by science and considered authoritative and absolute despite its erroneous assumptions and inherent ambiguities. For Australians in foreign environments, race was a constant, a lens through which to observe and a standard by which they could compare themselves to others and reassure themselves of their superiority.

Popular ideas of race and science informed three issues that regularly featured in Australian travel accounts: disease, depopulation and ethnic diversity. Australians instinctively remarked on their own health when first travelling in a foreign and tropical environment. As they acclimatised, their initial concerns about disease were replaced by observations of the health of Pacific Islanders. In particular, Australian travellers commented on the widely perceived trend of depopulation in the region, providing their own verdict on popular explanations of its causes and influence. In doing so, travellers compared the progress of Europeans and Islanders to other foreign populations in the Pacific, particularly Japanese, Chinese and Indian. As Australians remarked on these issues, they fell back on 'scientific' assumptions that were considered self-evident and absolute. However, complex individual encounters of travel produced a diverse range of responses, with scientific theories and racialist terminology being used, misused, conflated, indiscriminately applied and occasionally challenged by Australian travellers.

\section{Science and Stasis}

The role of the Pacific Islands in complex racial debates that occurred in Europe and the US have been the subject of much scholarly study, but how these ideas were applied by ordinary travellers from the periphery of empire is less clear. The discourses of science and travel have remained intertwined in representations of the Pacific since early exploration. Initially, the collection of new information from the 1760s onwards about non-white people from a stream of naturalists, anthropologists, surveyors, missionaries and ethnographers (both amateur and professional) informed scientific debates and encouraged subsequent travel to Oceania to verify racial theories. As travel writing became increasingly valued as a form of education and as a valid contribution to the public record, the objective and scientific traveller's account was perceived to be more accurate and 
trustworthy. ${ }^{2}$ By the 1880 s, Australian travellers were influenced by new scientific disciplines that had been developed in Europe; this can be evidenced in the growth of domestic scientific associations, the adoption of scientific language in twentieth-century tourist accounts and the popularity of certain practices (e.g. collecting human skulls). ${ }^{3}$ Science was gradually adopted as a tool for travellers to authenticate their experiences and legitimate their work, as well as a method for writers to publicise their accounts as educative and informative.

Ordinary travellers' interpretation and application of scientific theories were varied. Warwick Anderson demonstrated that an individual's understanding of human difference was 'a situated knowledge'; Anderson had used the example of Australian doctors who were influenced by local training, clinical observations and their own personal experiences as much as they were by European theories. ${ }^{4}$ Similarly, Australian travellers did not often refer to 'key' figures or debates in academic disciplines and had used classification terms interchangeably and indiscriminately. A history of race relations in colonial Queensland argued that weekly periodicals provided readers 'with a wealth of illustrative material which both popularised scientific racist theories and provided plenty of local examples to bear these theories out'. ${ }^{5}$ Evans, Saunders and Cronin argued that phrases such as 'survival of the fittest' and 'white superiority' were widely adopted due to the popularisation and simplification of scientific theories by journalists and politicians. This simplification obscured the complex debates about human difference and development that had occurred since the fifteenth century and contributed to fixing the Islander as a static ideal in the eyes of Australian travellers.

Bronwen Douglas has outlined the history of the term 'race' and the development of what she called 'the science of race' in Europe-namely, the 'systematic efforts in the new 19th-century disciplines of biology and anthropology to theorize collective physical differences between broad human groups as innate, morally and intellectually determinant, and possibly original'. ${ }^{6}$ It was this science of race that Australian travellers in the twentieth century took for granted before embarking on their

2 Hulme and Youngs, The Cambridge Companion to Travel Writing, 20, 53.

3 Michael E Hoare, 'Science and Scientific Associations in Eastern Australia, 1820-1890' (PhD thesis, The Australian National University, 1974).

4 Anderson, The Cultivation of Whiteness, 4.

5 Evans, Saunders and Cronin, Race Relations in Colonial Queensland, 15.

6 Douglas, Science, Voyages, and Encounters in Oceania, 7; Douglas, 'Climate to Crania'. 
journeys. They often overlooked the complex philosophical debates that had occurred over several hundred years. Measuring human difference according to physical appearance (particularly skin colour) had much older origins, with comparisons of bodily characteristics between black and white to be found as early as the mid-fifteenth century, in references to the slave trade in West Africa. Although this dichotomy bore connotations that privileged white-skinned people, collective terms used by explorers to describe people were nominalist and neutral in the sixteenth and seventeenth centuries. A Christian theological perspective of a common humanity remained influential until the late eighteenth century. It was a position that attributed human diversity to external factors and that supported humanity's universal potential for progress. ${ }^{7}$

Douglas identified a major discursive shift from human similitude to difference in the late eighteenth century, towards the assumption that rather than being subject to external change, race was innate and hereditary. This is evident in the meaning of the term itself, which shifted from a broad definition to a more specific anatomical and biological definition. No longer a general grouping, 'race' was a specific and essentialising label that was later indiscriminately applied by Australian travellers:

Thus naturalized as an invariable, fundamentally differentiating, measurable human physical quality with axiomatic social, moral, and intellectual correlates, the idea of race acquired the scientific authority which guaranteed its unquestioned realism over at least the next century. ${ }^{8}$

Consequently, attitudes to human difference hardened, with the inferiority of non-Europeans being attributed to human deficiencies rather than environmental or historical factors.

According to popular theories of race, the Pacific Islander became locked in a racial hierarchy in which Melanesians were inferior to Polynesians. This relationship remained unquestioned by travellers from the Australian mainland from 1880 to 1941 . White supremacy was assured on this ladder, and Aboriginal Australians were relegated to the very bottom. This view was articulated by the first European settlers in Australia, such as British marine officer Watkin Tench, who believed in 1793 that Aboriginal Australians 'rank very low, even in the scale of savages' and that they were

7 Douglas, 'Climate to Crania', 35.

8 Douglas, Science, Voyages, and Encounters in Oceania, 14. 
inferior to 'the subtle African; the patient watchful American; or the elegant timid islander of the South Seas'. natural history had encouraged the popular concept of human varieties that are differentiated according to stages of progression from savagery to civilisation. ${ }^{10}$ Australian anthropologist Alfred William Howitt was an early authority on Aboriginal culture in the 1880s, who wrote:

\begin{abstract}
The progression theory $\ldots$ is of modern origin, and has arisen through the scientific investigation and comparison of the social condition and customs of savage and barbarous races, of the survivals of archaic customs still met with among civilised peoples, and of the most ancient written records left to us from the past. ${ }^{11}$
\end{abstract}

The subtle differences that are perceived to separate these varieties based on physical appearance, moral and intellectual development, political organisation, agricultural production and the nuances of scientific debate and classification were often overlooked by non-scientific travellers. This is evident in the indiscriminate use of various classifying terms such as 'Malay', 'Negro', 'Ethiopic', 'Papuan' and 'African'. The potential for confusion was highlighted by British anthropologist Charles Gabriel Seligmann, whose work, The Melanesians of British New Guinea (1910), proposed the idea of renaming Papuans (the inhabitants of New Guinea) to 'Papuasians' and of dividing them into 'western Papuasians' and 'Papuan-Melanesians'. ${ }^{12}$ Not all Australian travellers made the distinction between Papuans and Melanesians, let alone using Seligmann's specific categories. Similarly, the terms 'Polynesian', 'Kanaka' and 'South Sea Islander' had different usages over time. They were applied to specific regions within the Pacific and were then used more generally as a reference to all Pacific Islanders.

9 Watkin Tench, A Complete Account of the Settlement at Port Jackson in New South Wales: Including an Accurate Description of the Colony; Of the Natives; And of Its Natural Productions/Taken on the Spot (London: G. Nicoll and J. Sewell, 1793), 187.

10 Bronwen Douglas, 'Philosophers, Naturalists and Antipodean Encounters, 1748-1803', Intellectual History Review 23, no. 3 (2013): 389-91, doi.org/10.1080/17496977.2012.723343.

11 Alfred William Howitt, in Lorimer Fison and Alfred William Howitt, Kamilaroi and Kurnai: Group-Marriage and Relationship, and Marriage by Elopement, Drawn Chiefly from the Usage of the Australian Aborigines: Also the Kurnai Tribe, Their Customs in Peace and War (Melbourne: George Robertson, 1880), 339.

12 Charles Gabriel Seligmann, The Melanesians of British New Guinea (Cambridge: Cambridge University Press, 1910), 1. 
Evidence of the influence of racial thinking on Australian travellers is difficult to find in their written accounts. As Angela Woollacott argued, white Australian travellers in the 1900s frequently came from urbanised areas and were unfamiliar with other ethnicities; therefore, 'whiteness was more an assumed superiority than a frequently practiced subordination of others. ${ }^{13}$ A common practice after arrival was to situate Islanders within a racial order, often in comparison to others that had been encountered along the journey. This was accomplished with short, matter-of-fact statements that were usually based on physical characteristics. Whether this was an unconscious process or a tool to qualify one's first impressions by making a scientific reference is unclear. For example, naturalist Albert Stewart Meek wrote in his 1913 travel account:

There are two distinct types of native in the Solomons. At the west end of the Solomons ... they are much darker than the Papuan. At the east end of the group they are more like the Papuan in colour and in character. ${ }^{14}$

References to 'types' and shared racial characteristics, both physical and mental, reinforced the common assumption that Islanders were fixed within a rigid racial hierarchy. This resonated with popular tropes within the literature that portrayed Islanders as primitive, frozen in time and infantile_-'an idle people, living in the most primitive condition, so luxuriously supplied by nature that they are dying off, mainly from pure inertia'. ${ }^{15}$

Strict racial categories also served a colonial purpose. Damon Salesa argued that race was 'a comparative dimension that made the Empire easier to archive, signify, consume, integrate and administer'. ${ }^{16}$ The need to train colonial officers for the mandated territory of New Guinea stimulated the creation of the first anthropology department in Sydney in 1925. ${ }^{17}$ For other groups with vested interests in the Pacific (most notably missionaries and businesses), signs of progress or stagnation among races were highly contested. People were assigned traits and were forced

13 Woollacott, To Try Her Fortune in London, 175.

14 Meek, A Naturalist in Cannibal Land.

15 Reverend AS Webb, in Allen, Stewart's Handbook of the Pacific Islands, 54.

16 Damon Ieremia Salesa, Racial Crossings: Race, Intermarriage, and the Victorian British Empire (Oxford: Oxford University Press, 2011), 12.

17 McGregor, Imagined Destinies, 103. 
into types to support a claim to authority. For individual travellers, as Woollacott demonstrated, how they articulated their own whiteness in comparison to others asserted privilege and power. ${ }^{18}$

Armed with several scientific theories that have established ordered racial hierarchies in the Pacific, Australian travellers were reluctant to contradict these categories. Yet, their travel accounts described a vibrant and ethnically diverse Pacific. They revealed the difficulties of fitting particular Islands and Islanders into types and models, which proved to be much more ambiguous and contested than the popular Melanesian-Polynesian dichotomy. Even some Australian researchers wrote travel accounts for a broader public market, choosing to avoid (or criticise) the constraints of scientific discourse. Australian naturalist (and amateur anthropologist) William Ramsay Smith was one of these travellers. He reflected on the value of travel accounts in his own travelogue, based on his tour of the Pacific Islands in the early 1920s:
Travellers provide much information of a scientifically trustworthy nature when they record their own observations among various peoples in different parts of the world and the comparisons they have drawn from these observations. And their evidence is almost of a different sort for what is collected by an investigator in a central anthropological laboratory, being a sort of intuitional spark that lights up a conclusion without a long and painful investigation ending in perhaps doubtful inferences. ${ }^{19}$

For Smith, Captain Cook was the 'ideal traveller, observer and reporter' because he embodied the ideals of both a scientific mind and an adventurous spirit.

Subsequent Australian travellers expressed a similar sentiment in their travel accounts. Although many were excited by the promise of adventure in a foreign environment, they were also informed by scientific knowledge, including medical theories of disease and the effects of the tropical climate on European bodies. Many Australian travellers faced a similar process of acclimatisation while they travelled to the Islands-their accounts revealed a general concern with preserving their health as they travelled in a foreign and potentially threatening environment.

18 Woollacott, To Try Her Fortune in London, 44.

19 Smith, In Southern Seas, 225. 


\section{Disease in the Tropics}

Disease was a common topic of observation within Australian travel accounts. Travel to any foreign environment prompted an instinctive response, as travellers expressed feelings of vulnerability and a fear of contagion. So prevalent was this response that the Oxford Book of Australian Travel Writing argued that cleanliness was a major theme. ${ }^{20}$ With the exception of labour recruiters, who frequently wrote about the health of the recruits that they were transporting, Australian travellers did not often dwell on this subject. They instead preferred to focus on more exotic and pleasing subjects. It is likely that most Australians were unfamiliar, if not unconcerned, with medical explanations of disease. Rather, concern for health and disease in travel accounts reflected a broader colonial discourse that Rod Edmond argued was 'central to the construction of boundaries in both nation and empire. ${ }^{21}$ Disease was racialised and sexualised, and the health of Australians became a standard against which to make judgements about the inferiority of Pacific Islanders and the superiority of the Australian 'stock'. These judgements reflected debates within Australia about the northern tropical region and the suitability of white settlement in the tropics.

Prospective travellers to the Pacific Islands were usually well informed about the prevalence of disease and the potential dangers that were specific to the Pacific. They could read news reports of contagion outbreaks, anthropological and historical documents recording the spread of disease, fictional tales of fevers and leprosy and the observations that were detailed in travel accounts. Commentary on Island hygiene and disease was also a crucial part of the discourse of settlement. Guidebooks had sections subtitled 'health' and 'climate', which explained the various diseases that were prevalent in specific islands, as well as the hospital and medical services available. The Pacific Islands Yearbook in 1932 pronounced that Fiji was 'probably the healthiest tropical climate in the world', that Hawai'i was 'famed for its climate', that the New Hebrides was 'unhealthy' (although 'not worse than that of many other tropical places'), that Samoa was 'mild and equable' and that the Solomon Islands were 'unfavourable for Europeans on account of its humidity and constant heat, and particularly

20 Pesman, Walker and White, The Oxford Book of Australian Travel Writing, xv.

21 Rod Edmond, Leprosy and Empire: A Medical and Cultural History (Cambridge: Cambridge University Press, 2006), 11. 
on account of the prevalence of malaria', while Tahiti's climate was not mentioned at all. ${ }^{22}$ Shipping advertisements and travel handbooks responded by promoting the health benefits of visiting a tropical climate during the Australian winter months:

Enabling the people of Australia to escape the cold winter months and visit the tropics during the continuance of the cool and healthy south-east trade winds, which blow from the South Pacific from April to November. ${ }^{23}$

Passage on a ship was the first environment in which Australians encountered disease. Sea travel allowed for more gradual acclimatisation to the tropical climate, although conditions on the ship varied from luxurious to overcrowded and stuffy. The oppressive weather was a common complaint, with heat and dampness making the voyage uncomfortable and tiresome, and seasickness leaving passengers weak. Close-quartered living facilitated the spread of disease, with travellers sometimes refused entry ashore because of sickness onboard. ${ }^{24}$ Absent from the accounts of travellers is any concern with the quality of food and water (both on and offshore) in relation to gastrointestinal illnesses. Only artist Aletta Lewis recalled consuming infected food aboard the American warship USS Ontario in 1929..$^{25}$ Instead, malnutrition and dysentery were frequently observed in the Islander population, often as part of an evaluation of their suitability for labour.

The threat of disease transmission was reinforced by strict quarantine regulations that were imposed before passengers could disembark. The devastating effects of highly contagious diseases such as influenza or measles were demonstrated in mass epidemics in the world and in specific outbreaks in the Pacific Islands. The $1918 \mathrm{flu}$ pandemic spread throughout the Pacific Islands, with only American Samoa and New Caledonia employing effective quarantine that prevented outbreaks. ${ }^{26}$ Similarly, 13 per cent of the Rotuman population died in 1911 from the measles because the medical staff of the port authority were absent when

22 Robson, The Pacific Islands Yearbook, 55, 101, 186, 211, 231, 263, 309.

23 Allen, Stewart's Handbook of the Pacific Islands, 85-6.

24 For example, see Nossiter, Southward Ho!, 103; Doorly, In The Wake, 294; Chewings, Amongst Tropical Islands, 27, 31.

25 Lewis, They Call Them Savages, 231.

26 Sandra M Tomkins, 'The Influenza Epidemic of 1918-19 in Western Samoa', The Journal of Pacific History 27, no. 2 (1992): 181, doi.org/10.1080/00223349208572706. 
a passenger boat arrived. ${ }^{27}$ Quarantine control was essential for protecting the Australian mainland, as much as it was for protecting the Islands. The transfer of the bubonic plague to San Francisco from a steamship returning from Honolulu in 1900 was a reminder of the potential dangers that unrestricted mobility in the Pacific Ocean posed. ${ }^{28}$

Once ashore, the most obvious signs of disease were visible skin diseases. Travellers noted rashes, lumps, boils and sores, such as yaws (a common infectious disease prevalent until the 1950s and 1960s). As Caroline David explained in 1899:

There were Fiji sores, sprained ankles, tropical bilious attacks and sunburn, yaws or tonu, as the Funafutians call it, lafa and magesu (Tokelau ring-worm and itch) ... [T]he tropical sores were the most troublesome ailments; the least scratch, unless at once disinfected and covered from flies, would inflame and develop into an ulcer needing constant care. ${ }^{29}$

Skin diseases were commonly attributed to poor cleanliness and personal hygiene standards, with colonial travellers articulating their judgements in racial and denigrating language. Julian Thomas claimed that New Hebridean labour recruits 'ate their meals like apes', while Beatrice Grimshaw made the following observation in a Fijian village:

Their clothes—only a loin-cloth apiece-were unspeakably dirty, and every unoccupied moment seemed to be spent in hunting through each other's huge frizzled heads for certain small game, which when found, was immediately eaten by the finder ${ }^{30}$

Such biased criticisms contradicted popular romantic notions of naked freedom and primitivism in the Islands.

Although not as common, the stigma that was attached to the incurable diseases of leprosy and elephantiasis, and the physical deformities that they caused, made them a subject of fear and fascination for travellers. Elephantiasis, also known as lymphatic filariasis, is caused by parasitic worms that are spread by the bites of infected mosquitoes; its cause and remedies were not well known in the early twentieth century. Australian

27 G Dennis Shanks et al., 'Measles Epidemics of Variable Lethality in the Early 20th Century', American Journal of Epidemiology 179, no. 4 (2014): 2, doi.org/10.1093/aje/kwt282.

28 James K Ikeda, 'A Brief History of Bubonic Plague in Hawai i', Hawaiian Entomological Society 25 (1985): 75-81.

29 Edgeworth David, Funafuti, 48.

30 Thomas, Cannibals and Convicts, 336-7; Grimshaw, From Fiji to the Cannibal Islands, 120-1. 
meteorologist Clement Lindley Wragge in 1906 expressed anxiety when sharing food with an infected person and Lewis was upset in 1929 when her friend contracted the disease in American Samoa: 'It was intolerable to think of Ava's straight, well-formed body falling into the clutches of this inexorable disease'. ${ }^{31}$ Descriptions of the disease emphasised 'the horrifying proportions that made a grotesque of a man', in the words of plantation overseer Eric Muspratt, who observed in the 1920s disfigurement so extreme that one man carried his swollen parts in a wheelbarrow. ${ }^{32}$ Although it was not fatal, elephantiasis caused poverty and social stigma—a consequence that Sydney Walter Powell feared in the 1910s, when he was diagnosed in Tahiti: 'I have elephantiasis, an abominable disease, which for months past I have dreaded ... when the doctor told me I must leave here I dreaded banishment and forgot the disease'. ${ }^{33}$

Leprosy was also a widespread disease with a severe social stigma. The first International Leprosy Congress in 1897 in Berlin recommended the isolation of patients, based on medical thought that the disease was highly contagious and incurable. Consequently, colonial governments established quarantine stations on small, remote Islands throughout the Pacific for leper isolation. ${ }^{34}$ Fear of contagion meant that missionaries and volunteers often provided care to these people. These Islands fascinated Australian travellers who passed by at a distance, in a similar way that the sublime decay of ruins and prisons attracted the subversive tourist, though face-to-face encounters were avoided. Arnold Safroni-Middleton, a wandering artist and musician in the late nineteenth century, wrote tales that featured a Hawaiian leper girl who was symbolic of the romanticism of 'martyrdom' and forbidden romance. ${ }^{35}$ The leper colony on Moloka'i Island in Hawai' $\mathrm{i}$ was the most well known to Australians, made famous by the popular figure of its caretaker, Father Damien DeVeuster. The example of Moloka'i highlights the importance of Christian charity and sympathy, while also demonstrating how colonial governments regarded the disease as 'a symbol of native inferiority and ineptitude, requiring the custodial attention of foreigners with their assumed superior intelligence. ${ }^{36}$

\footnotetext{
31 Wragge, The Romance of the South Seas, 108; Lewis, They Call Them Savages, 235.

32 Muspratt, Fire of Youth, 43.

33 Powell, $A$ South Sea Diary, 62.

34 Jane Buckingham, 'The Pacific Leprosy Foundation Archive and Oral Histories of Leprosy in the South Pacific', The Journal of Pacific History 41, no. 1 (2006): 82. doi.org/10.1080/00223340600652441.

35 Safroni-Middleton, In the Green Leaf, 135, 197.

36 Gavan Daws, Holy Man: Father Damien of Molokai (New York: Harper \& Row, 1973); Pennie Moblo, 'Leprosy, Politics, and the Rise of Hawai i's Reform Party', The Journal of Pacific History 34, no. 1 (1999): 88, doi.org/10.1080/00223349908572892.
} 
Although encounters with elephantiasis and leprosy were limited, it was the threat of fever that posed a greater danger to Australians- the most common being malaria, consumption (i.e. tuberculosis) and 'blackwater fever' (a complication of malaria). Other fevers included yellow fever, scarlet fever, cholera, chicken pox, typhoid, smallpox and polio. Labour recruiter A Nixon noted on 2 July 1877 about Erromango that it is a most unhealthy island. Fever ague and chest diseases seem to be ... prevalent ${ }^{37}$ In 1897 , fevers were known to be spread by mosquitoes and were endemic in certain regions, so travellers were aware of the need for mosquito nets while visiting the Pacific Islands. Those who fell ill in the Islands wrote vivid accounts of their experiences and strong warnings to prospective travellers. Jack McLaren, who suffered malaria and yaws in the 1900s, explained how 'despite the barbarity, treachery and cunning of the natives, I think the greatest danger in the Solomons was from disease'. ${ }^{38}$ In 1934, British traveller Richard Reynell Bellamy recalled the climate in Australia and in the Pacific, admitting that his health had influenced his observations:

Perhaps it was not actually so hot as places I had been in on the Queensland coast, and my bad health might have been the reason for my feeling it to such an extent. Certainly I found it unbearable. ${ }^{39}$

Similarly, Meek looked forward to returning to Australia to 'recruit my shattered health' ${ }^{40}$

Fear of fever was linked to a fear of the tropical environment as a cause of disease, and early colonial settler discourse about the northern Australian tropics informed expectations and observations about the Pacific. Acclimatisation to new and foreign environments was a slow and inconsistent process, as Anderson revealed in his history of the early colonial settlement of Australia. ${ }^{41}$ Although the temperate southern climate of the continent had become normalised by the 1870 s, the suitability of the tropical north for European settlement was still contested. This concern also applied to the tropical Pacific Islands, as one 1920 handbook noted:

37 A Nixon, 'Inwards Correspondence', in Colonial Secretary's Office, Series ID 5253, Item ID 846982 (Brisbane: Queensland State Archives, 1877).

38 McLaren, My Odyssey, 244.

39 Bellamy, Mixed Bliss in Melanesia, 267-70.

40 Meek, A Naturalist in Cannibal Land, 196.

41 Anderson, The Cultivation of Whiteness, 37. 
It [New Caledonia] would not be so healthful as Australia, which has its cleansing and purifying hot, dry winds, and its healthgiving odours from eucalypt forests as well as a population rather more observant of sanitary conditions, and, perhaps, the practice of the virtues. ${ }^{42}$

Fears of disease were founded on actual incidences of European deaths in tropical climates, yet this anxiety was also encouraged by exaggerated and distorted stories. Raphael Cilento, an Australian medical administrator and tropical health expert in the 1920s and 1930s, believed that the tropics were a region of imagined danger:

To the great majority of the inhabitants of temperate climates, the word 'tropical' conjures up visions of sweltering mangrove flats, the haunts of the crocodile; of rank and steaming forests that exhale the musky odour of decaying vegetation and conceal within their leafy depths 'miasmic' swamps; of deadly snakes and of the skulking savage with his poisoned spear. ${ }^{43}$

Indeed, these notions often appeared in Australian travel accounts. Trader Joseph Dickinson described 'an abomination of stench and flies' in Ugi, while Thomas was wary of 'noxious odours' that emanated from the ground in Tanna. Powell believed that the soil of Tahiti had caused elephantiasis in his foot. ${ }^{44}$ Travellers regularly warned readers about the dangers of the tropics and suggested preventative measures.

The hot environment was also believed to affect the body and mind, sometimes termed 'colonial fever' or, in Cilento's case, 'heat stagnation'. From 1899 to 1906 , colonial governments established schools in tropical medicine to test the suitability of races in tropical environments and the use of vaccines. These schools provided scientific backing to the notion that the tropical environment could induce laziness and physical, moral and psychological degeneration. ${ }^{45}$ The fear of 'going native'-which had long been expressed as both fantasy and anxiety in European literature about the Pacific-became scientifically verified and located in the tropics. By World War II, Australian troops fighting in the Pacific Islands

42 Allen, Stewart's Handbook of the Pacific Islands, 62.

43 Raphael Cilento, The White Man in the Tropics: With Especial Reference to Australia and Its Dependencies (Melbourne: H.J. Green, Commonwealth Department of Health, 1925), 7.

44 Dickinson, A Trader in the Savage Solomons, 128; Thomas, Cannibals and Convicts, 292; Powell, 'Each to His Taste', 200.

45 Anderson, The Cultivation of Whiteness, 119. 
used the phrase 'to go troppo' to describe a loss of sanity. Australian travel accounts frequently reiterated fears of white degeneration. Muspratt observed one Australian plantation overseer in the Solomon Islands who had 'practically gone native struggling with a poorly-equipped and fever-stricken plantation' and blamed the environment for leaving him 'broken' and 'so full of fever that he trembled continually'. ${ }^{46}$ On his solo sailing voyage from Sydney to California, Fred Rebell claimed to feel 'Malua fever', an imagined disease 'of procrastination and disinclination to work'. ${ }^{47}$ Travellers also described beachcombers and residents who were 'wrecked by alcoholism' and who warned travellers that the Islands were not suitable for women or children. Powell's criticism of European weaknesses was framed in terms of progress:

The European can rise higher than the Tahitian, but he can sink immeasurably lower. It makes me wince to see the common white man beside the common native; physically, mentally and morally he is the native's inferior. It is not his fault: degeneration has followed degradation, as nothing can prevent it from doing. ${ }^{48}$

As racial theory gained popularity, a more hereditary perspective of disease shaped medical thought in Australia from the 1880s onwards. This did not completely displace environmental factors, nor did it become conventional until the early twentieth century. For example, germ theory was also influential in identifying other humans (and animals) as potential carriers of disease, rather than genetics. Yet policies of racial segregation could be justified by both hereditary and environmental explanations. This became formalised with the White Australia policy, as immigration and quarantine acts restricted the flow of people, particularly Asian immigration. As Anderson demonstrated, Federation became couched in scientific terms and white Australia was represented as a scientific experiment. In this experiment, the tropics were situated on the boundary and were considered distinctly as a 'separate, racially dubious territory'. ${ }^{49}$ In some cases, the tropics were argued to consume the white race-a belief that was used by many proponents of the Queensland labour trade from 1863 to 1906 to justify their claim that white labour was unsuitable for the tropics. The trade, which was driven by the demand for cheap Islander labour on Queensland's sugar plantations, was vigorously debated in public.

46 Muspratt, My South Sea Island, 45, 48.

47 Rebell, Escape to the Sea, 88-9.

48 Powell, A South Sea Diary, 42.

49 Anderson, The Cultivation of Whiteness, 73-4, 114. 
An alternative response was that the tropics would cultivate a new version of the 'coming man', or as Cilento described him, 'a definite type of North Queenslander, or tropical-born Australian'. ${ }^{50}$ A growing number of Australians visiting and residing in the tropics from the 1900s onwards proved this point. In northern Queensland, the collapse of the labour trade had forced more white settlers to work, which undermined the notion that white labour was unsuitable in the tropics. In the Pacific Islands, the experiences of resident traders, plantation overseers, missionaries and colonial officials provided additional evidence that challenged this assumption. Their accounts describing day-to-day life often discussed the effects of European disease, as their engagement required them to sustain a healthy labour force for the plantation (as in the case of Muspratt), supervise and educate a congregation for the mission (as in the case of Helen Cato) or maintain good relationships with their neighbours (as in the case of David). ${ }^{51}$ Concerted efforts by governments and businesses to encourage tourism and economic investment in the region by promoting a healthy climate contributed to the tropics and tropical diseases becoming less feared over time.

\section{Depopulation}

Depopulation was a trend widely believed to exist in the region, with Australian travellers often drawing on misguided racialist assumptions to understand and explain it. Australian anthropologist Herbert Ian Hogbin wrote in 1939, 'Everyone who has the smallest acquaintance with the literature of the Pacific is familiar with one at least of the effects of contact with the outside world, depopulation'.52 Depopulation was accepted by most Australians as being self-evident, and as such, travellers often referred to the issue, but rarely dwelled on it. This was a notion applied to Aboriginal Australians as well, as Woollacott argued:

By the last decades of the nineteenth century, white Australians, with Western beliefs in social Darwinism and eugenics supporting them, assumed that Aboriginal people were dying out. That assumption was so pervasive and secure that the fate of Aborigines was little discussed. ${ }^{53}$

50 Cilento, The White Man in the Tropics, 73-4.

51 Muspratt, My South Sea Island; Cato, The House on the Hill; Edgeworth David, Funafuti.

52 Herbert Ian Hogbin, Experiments in Civilization: The Effects of European Culture on a Native Community of the Solomon Islands (London: Routledge \& Sons, 1939), 125.

53 Woollacott, To Try Her Fortune in London, 173. 
Scholars such as Norma McArthur and Donald Denoon have since shown that population estimates that were made before European contact and during the colonial period were plagued by absences, inaccuracies and inconsistencies. ${ }^{54}$ Nonetheless, it was a popular and pervasive idea on which Australians frequently commented.

The most common explanation for depopulation that travellers cited was European disease. Many were well aware of the disastrous effects of past epidemics that were caused by early explorers and more recent visitors (e.g. the outbreak of measles in Fiji in 1875). These events were highly publicised and well known within Australia, and accounts usually stressed the immediate and detrimental effects on the population, overlooking other factors such as population growth and recovery. Frank Coffee offered one example that reminded readers of the high death rates in Fiji in 1875 (which he estimated to be 40,000):

Fiji affords a striking example of the direful results to be apprehended from exposing a race to a new disease, even though such a malady is comparatively harmless in respect to those who have become in the course of ages accustomed to its effects. ${ }^{55}$

Although improvements in quarantine were significant in preventing widespread outbreaks of diseases across island groups, some Australians also believed that Islanders had developed a resistance to European diseases as part of the evolutionary process. In 1932, Bishop Cecil Wilson discounted 'illnesses which steamers from Sydney often brought with them' as a factor that contributed to depopulation. He argued that Islanders were 'hardy and did not seem to be much affected'.$^{56}$ Only in very isolated Islands could a contemporary effect be observed, such as David's visit to Funafuti in 1897:

We were thoughtful enough to bring with us from Fiji a fine assortment of influenza germs, and these ran riot among the native population. A few days after our arrival two-thirds of the people were down with it, and dismal objects they looked. ${ }^{57}$

54 Norma McArthur, Island Populations of the Pacific (Canberra: Australian National University Press, 1968), 345-54; Donald Denoon, 'Pacific Island Depopulation: Natural or Un-Natural History?', in New Countries and Old Medicine: Proceedings of an International Conference on the History of Medicine and Health, ed. Linda Bryder and Derek A Dow (Auckland: Pyramid Press, 1995).

55 Coffee, Forty Years on the Pacific, 171.

56 Wilson, The Wake of the Southern Cross, 184.

57 Edgeworth David, Funafuti, 52. 
A more probable encounter was with diseases that were caused by poverty, malnutrition, overcrowding and dispossession. Growing urban centres and plantations were potential sources of diseases like tuberculosis because of their higher population density. In the case of plantations, poor working conditions placed Islanders at increased risk. This was framed as a clash of primitive and modern, in which 'civilisation intrudes with toil, disease and drabness and the Pacific yields to its advance. ${ }^{58}$ Comments were more often focused on moral corruption in the main urban centres, with descriptions of sexual promiscuity and alcohol abuse attributed as both cause and symptom of depopulation. For government agent Douglas Rannie, depopulation in the New Hebrides was a combination of 'natural laziness, filthy habits and syphilis ... and from the vices of drink introduced by white men. ${ }^{59}$ He was also critical of mission rules that forced Islanders to wear ill-fitting clothes-which was a criticism regularly applied by others opposed to missionary influence and then reiterated in the 1920s and 1930s by those lamenting the erosion of traditional ways of life. Diseases of development may have been easily observable in the main towns and ports, but travellers' ability to evaluate the healthiness of an Island was limited, as they did not often venture further inland. In some cases, a traveller could misinterpret the absence of sick people in villages as a sign of healthiness, rather than as one of low life expectancy. ${ }^{60}$

Depopulation was also blamed on generalised racial deficiencies that were attributed to Pacific Islanders-including their supposed physical weakness, moral and psychological immaturity and primitive behaviours and customs. Coffee's explanation of Fiji's depopulation was typically vague, placing blame on both parties by describing:

The comparatively weak maternal feeling of Fijian women (the infant mortality being very high), the introduction of new diseases, such as measles, whooping-cough, influenza, etc., with which the natives cannot cope, and the disappearance of many of their old social customs. ${ }^{61}$

58 Fox, Oceania, 3.

59 Rannie, Notes on the New Hebrides, 25.

60 Denoon, 'Pacific Island Depopulation', 329.

61 Coffee, Forty Years on the Pacific, 171. 
The supposed childlike, irresponsible and lazy racial characteristics of Islanders were frequently cited as a major cause. In the 1910s, Ralph Stock described 'an irresponsible child, and, alas, a child who is dying', while Reverend John Wear Burton noted that:

If the average white resident of Fiji is questioned as to the prime cause of the decrease of the population, in four cases out of five the reply will be, 'Laziness — pure unadulterated laziness. ${ }^{62}$

Travellers who applied these racial stereotypes to Pacific Islanders found support in local government officials and missionaries, who stood to benefit from entrenched notions of Islander inferiority. Depopulation was a convenient tool for justifying colonial rule. For example, in response to the measles outbreak in Fiji in 1875, a Royal Commission was established in 1893 'to inquire into the decrease of the native population'. Three years later, it reported:

Consequently many must have died of starvation and neglect; but the heavy mortality was also attributable in great measure to the people's dire ignorance of the simplest nursing precautions, to their blind unimpressiveness, their want of ordinary foresight, their apathy and despair. They became at once ... overwhelmed, dismayed, cowed, abandoning all hope of self-preservation, and becoming incapable of any effort to save themselves or others. ${ }^{63}$

This report was widely circulated and interpreted by other travellers and residents in the early twentieth century, such as by Burton, whose mission publication, Fiji of To-Day, reviewed the commission's conclusions. In his summary, he represented mission work as necessary for combatting many of the alleged causes of depopulation ('inbreeding', 'epidemic diseases', 'the condition of women', 'the narcotic influence of the communal system', 'sexual depravity', 'premature civilization' and 'ignorance in the treatment of disease'). ${ }^{64}$

Causes of depopulation in the Pacific may have been unclear to Australian travellers, yet it was frequently assumed that all Pacific Islanders uniformly experienced the process. The supposed racial superiority of Polynesians did not make them more resistant to the 'inevitable' racial decline. In fact, the depopulation in Polynesia may have been in part due to the smaller

62 Stock, The Confessions of a Tenderfoot, 206; Burton, The Fiji of To-Day, 213.

63 BG Corney, J Stewart and BH Thomson, Report of the Commission Appointed to Inquire into the Decrease of the Native Population: 1893 (Suva: Edward John March, 1896), 36.

64 Burton, The Fiji of To-Day, 197-216. 
size and higher population density of the Islands and the longer period of European contact compared to Melanesia. ${ }^{65}$ The European myth making of Tahiti and French Polynesia as sites of desire were influential in shaping Australian attitudes to diseases there. The Polynesian region was idealised as a primitive paradise, and travellers who were disappointed upon arrival blamed disease and corruption, among other factors. As Muspratt noted: 'Some strange quality dwelt here, a lonely forgotten spirit now dying in isolation in this modern world. Like Honolulu, only more so.' ${ }^{36}$ A longer period of European contact with Polynesia resulted in a larger body of literature written by explorers and missionaries about disease and depopulation. In the literature, Polynesia was enshrined as being superior to Melanesia and was described as a land of sexual desire, with subsequent travellers aware of the European legacy of venereal disease. Powell noted that Tahiti suffered from 'disease due to debauchery' and that, for Tahitian women, 'to associate with foreign sailors is the utmost degradation'. ${ }^{67}$ For the missionaries who established themselves in French Polynesia before moving west, depopulation was a convenient myth to justify their work. ${ }^{68}$

If the Polynesian ideal was degraded by its long association with Europeans, then the Melanesian was supposedly doomed to die because of his or her racial inferiority. As a region less known to Europeans, Melanesia was imagined as being more diseased and more dangerous than Polynesia. It was bestowed the tropical imagery of decay and rottenness, and then it was compared to an idealised east that had higher and more vigorous races'. ${ }^{69}$ This was supported by the presence of diseases that were not commonly found in the eastern Islands (e.g. malaria). Its proximity to Australia-and reports from sandalwood, bêche-de-mer and labour trading within the region-had introduced stereotypes of Melanesian savagery and backwardness into the Australian public consciousness. According to Coffee:

The [Queensland] plantations turned out some of the most accomplished specimens of savage scoundrels imaginable-men who had grafted on to their originally depraved natures the vices of civilization, but none of its virtues. ${ }^{70}$

65 Denoon, 'Pacific Island Depopulation', 405.

66 Muspratt, Fire of Youth, 181.

67 Powell, Adventures of a Wanderer, 165.

68 McArthur, Island Populations of the Pacific, 160.

69 Burton, The Fiji of To-Day, 16.

70 Coffee, Forty Years on the Pacific, 105. 
Due to the scientific theories that situated people according to stages of development from savage to civilised, depopulation was considered a symptom of stagnation-or worse, degradation. In some cases, this became a call to action for Australians. For Presbyterian minister Charles Stuart Ross, the merits of Christian education were emphasised by describing the Fijian as being disadvantaged by 'centuries of moral degradation and intellectual atrophy'. ${ }^{71}$ For other travellers, it was accepted that extinction was the only outcome.

Australian attitudes to the Pacific Islands were informed by domestic policies and debates about Aboriginal Australians, who were assumed to be the most primitive and savage of races, and thus doomed to extinction. Considered inferior to Pacific Islanders (both Melanesian and Polynesian), Aboriginal Australians were widely expected to become extinct from the 1830s, an assumption that hardened throughout the early twentieth century. Although the Melanesian race of peoples was believed to possess the same ability to stagnate or degrade as Aboriginal Australians, white Australian attitudes towards the Pacific Islands were generally more positive. This was evident in government policies towards the territories of Papua and New Guinea. These were motivated by a concern for Australia's international image and a belief that Melanesians could be 'civilised' in a way that Aboriginal Australians could not. For example, in practice, this meant that only colonial officers working in Papua and New Guinea received specialised training in anthropology, geography and hygiene, despite the welfare of Papuans and Aboriginal Australians frequently coming under the control of the same ministerial office.

Comparisons between Pacific Islanders and Aboriginal Australians were rare in Australian travel accounts. This may be attributed to the focus on more exotic foreign images or the reality that few urban white Australians came into contact with Aboriginal Australians. ${ }^{72}$ Even for travellers who described their encounters with Aboriginal Australians and Pacific Islanders within the same text, they tended to confine each meeting to separate chapters and observed racial characteristics without cross-comparison. This suggests that the broader Australian population considered Aboriginal Australians and Pacific Islanders distinct and separate races, preferring Islanders because they were supposedly superior

71 Ross, Fiji and the Western Pacific, 133.

72 Woollacott, To Try Her Fortune in London, 175. Only William Ramsay Smith and John Wear Burton described encounters with Aboriginal Australians in detail. 
or more exotic. In these decades, Australians displayed a more active interest in civilising the Pacific than they did in advancing the Aboriginal Australian cause.

Australians began to articulate more clearly their roles and responsibilities in civilising the Pacific from the 1920s. War had energised a sense of Australian racial character, and the acquisition of new Pacific Island territories post-World War I gave further impetus to a more involved Australian position in the region. Writing in 1939, Hogbin argued that:

A definite obligation exists to encourage the social development of the natives so that they can eventually, after perhaps several generations, participate in the life of the world on the same sort of footing as ourselves. ${ }^{73}$

Depopulation provided a convenient cause for justifying Australian colonial presence (and, in some cases, a measure of its success). It resonated with the concerns of travellers post-World War I that the primitive and natural Pacific ideal was threatened.

Progress was encouraged in Pacific health and development, in the hope of arresting the alleged trend of depopulation. In Australia, doctors returning from the war felt empowered in managing populations, with the Australian government displaying a greater interest in tropical health, particularly driven by Cilento. Although this government interest faded by the end of the 1920s, Anderson argued that:

It was the biological utopianism of Cilento and his coterie that resonated most loudly outside the medical profession and health bureaucracies, as it appealed especially to those political radicals and bohemian writers who were trying in the 1930s to distinguish a new national character. ${ }^{74}$

Other nations were concurrently influencing health and disease in the Pacific, prompted by advances in medicine and postwar humanitarian sentiment. The Central Medical School in Fiji was the first of its kind in 1929, funded by the US philanthropic organisation, the Rockefeller Foundation. Building on the training programs developed in Fiji since the 1880 s, the school began training 'native medical practitioners' ${ }^{75}$

73 Hogbin, Experiments in Civilization, 231.

74 Hogbin, Experiments in Civilization, 129-36, 176.

75 Annie Stuart, 'Contradictions and Complexities in an Indigenous Medical Service', The Journal of Pacific History 41, no. 2 (2006): 143. 
Australian missions and businesses were also eager to broadcast their roles in developing health facilities and programs to combat depopulation. This is evident in a statement by Bishop Cecil Wilson in 1932, which was published in a children's reference book that promoted Anglican mission work in the Pacific:

I do not think that at the end of my seventeen years there had been any great decrease in the population ... Our Mission, with its doctors, its medicines, its high standard of family life ... and its opposition to harmful customs, could only help to stabilize the people, neutralize adverse influences and prevent the depopulation which so-called civilization, with its shoddy clothes, alcohol, firearms, and diseases, almost invariably brings to child races. ${ }^{76}$

NSW state politician Thomas Henley visited a Methodist mission hospital in Fiji in 1926 and praised the work of Australian staff there (see Figure 20). He published an account of his trip to promote the strategic value of the British colony to Australians. Similarly, businesses also referred to medical aid to promote and justify their colonial works. Albert Fuller Ellis's account of Ocean Island and Nauru attributed health and hygiene improvements in mining labour camps to the efforts of British colonisers-to justify the exploitative phosphate mining operations that were conducted on these Islands. ${ }^{77}$

Improved medical knowledge and treatment in the early twentieth century also shaped perceptions of disease in the Pacific, resulting in a diminishing fear of human carriers of disease and greater confidence in medicine. Further, medical and scientific discourses in the 1930s began to challenge 'formalist taxonomies of race', according to Anderson; he identified a shift in government policies towards Aboriginal Australians from isolation to assimilation. ${ }^{78}$ However, stereotypes remained persistent, as Stuart revealed in the records of the Fiji Annual Medical and Health Report of 1936 and 1938-these reports applied racialised traits to students, classifying Polynesians as 'sanguine', Melanesians as 'phlegmatic' and Micronesians as 'choleric'. ${ }^{79}$

76 Wilson, The Wake of the Southern Cross, 184.

77 Ellis, Ocean Island and Nauru, 135, 138.

78 Anderson, The Cultivation of Whiteness, 206.

79 Stuart, 'Contradictions and Complexities', 132. 


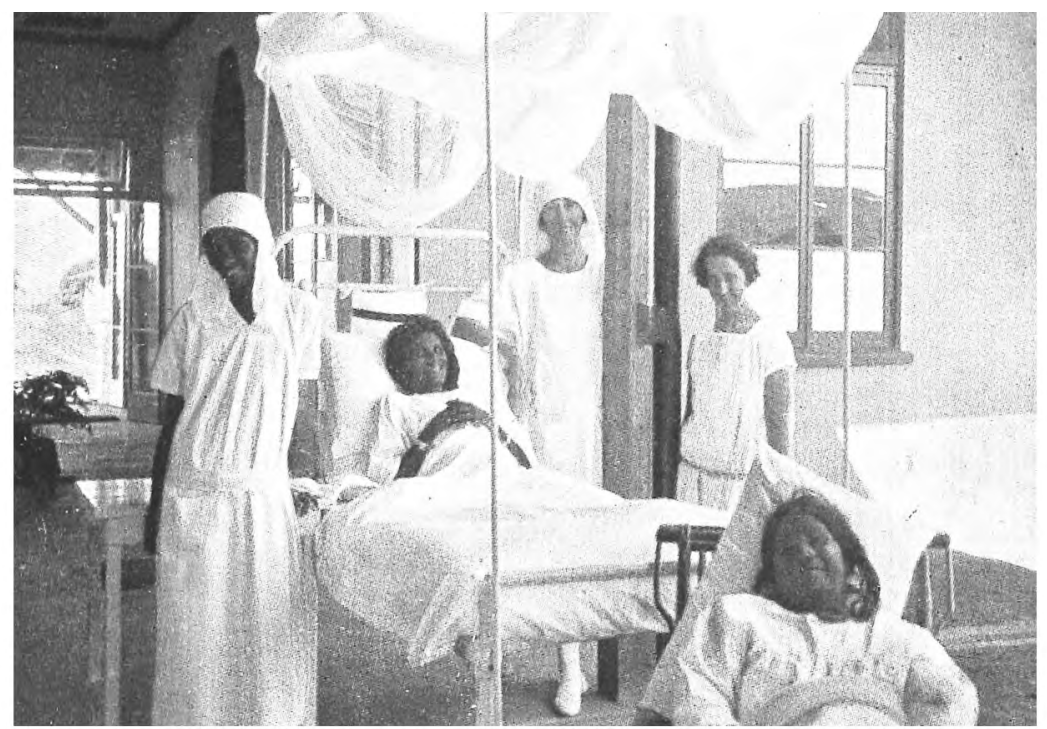

One of the Wards of the MethodistidMission "Hospital, Ba, Fiji.

Dr. Doreen Hensley, Resident Medical Missionary, late of Melbourne (standing behind the patient in chair); Matron Miss Clare Spencer, of Burwood, Sydney (standing at the head of the bed).
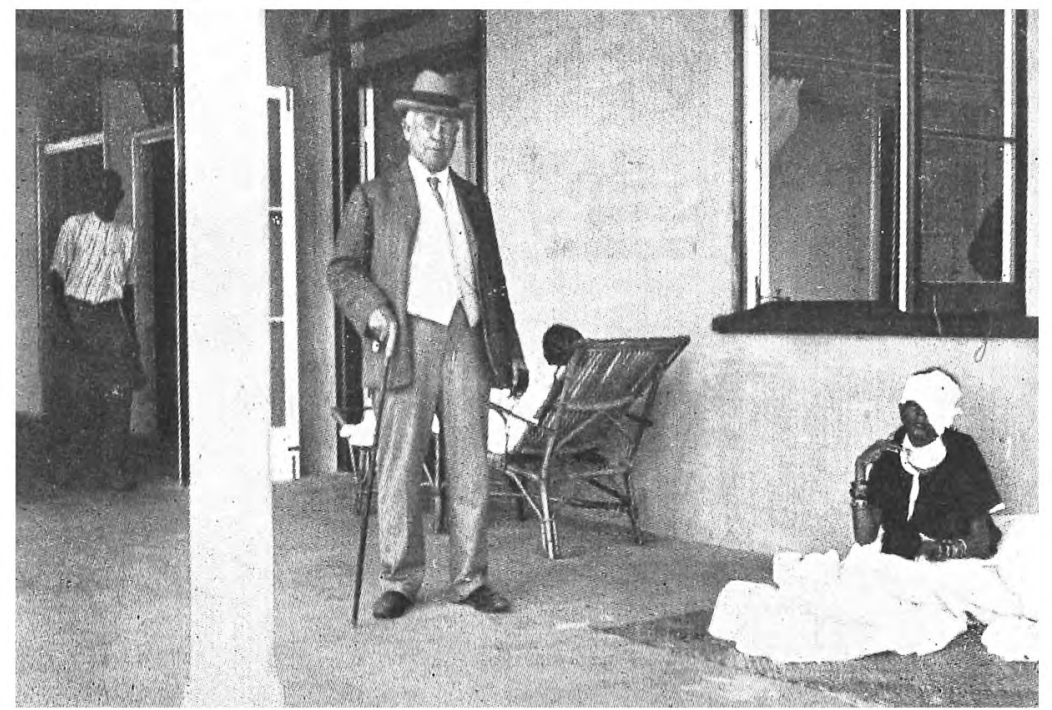

Sir Thomas Henley visiting the Hospital-July, r 926.

(One of the Sleeping-out Verandahs)

Figure 20: One of the Wards of the Methodist Mission Hospital, Ba, Fiji.

Source: Thomas Henley, Fiji-The Land of Promise (Sydney: John Sands Ltd, 1926), 48. 
For Australian travel writers, evidence of depopulation, degradation or progress was difficult to observe during their momentary encounters in the Islands. As sailor Alan John Villiers observed in the Solomon Islands in 1937, 'Tulagi is frankly and plainly a headquarters for white living ... where white meets white, lives with white, thinks white, and plays golf and tennis and cricket and so forth' ${ }^{80}$ The nature of travel thus reinforced the racialist assumptions that were popular in Australia at the time. Occasionally, some travellers would depart from these conventions. For example, Villiers's narrative of yachting in the Pacific was critical of the Australian administration and of its effects in the Solomon Islands, which led him to question 'whether new countries ... ought ever to be entrusted with the control of native races' ${ }^{81}$ Gold prospector John Archibald Fraser wrote in the 1930s that he considered the Fijian his 'brown-skinned brother', finding Fijian cannibalism to be no less moral than the British treatment of Aboriginal Australians. ${ }^{82}$ Similarly, young artist Aletta Lewis became deeply attached to the Samoan community with whom she temporarily lived in 1929, to the extent at which she forgot the division between 'his race and mine'. ${ }^{83}$ In 1939, lone adventurer and sailor Fred Rebell remarked:

There is something in those natives [of Fiji] which makes them accept life without a struggle ... And yet how much are these tendencies racial? How much are they merely climatic and geographical? ${ }^{34}$

The few travel accounts that depart from the conventional narrative of racialised human difference suggest that the contradictions of racial theory and policy in the Pacific were more clearly visible by the 1920s and 1930s.

\section{The Asian 'Invasion'}

Australian travel writers also noted the growth of the other populations in the Pacific Islands. Expecting a Pacific that was populated entirely by primitive Islanders and colonial white masters, travellers were instead surprised to find evidence of substantial Asian immigration throughout

80 Villiers, Cruise of the Conrad, 173.

81 Villiers, Cruise of the Conrad, 175-6.

82 Fraser, Gold Dish and Kava Bowl, 131.

83 Lewis, They Call Them Savages, 76, 109.

84 Rebell, Escape to the Sea, 88-9. 
the region. The economic success and population growth of Asian people in the Pacific were attributed to the assumed depopulation of Pacific Islanders, which made Asian peoples the target of negative and derogatory labelling. Specifically, Australian travellers commented on the high concentration of Japanese people in Hawai' $i$, Chinese in Tahiti and Indians in Fiji. These were high-profile stopover destinations for travellers, and Australians had different responses to each group, as well as a more general aversion to a perceived external Asian threat. Anti-Asian immigration policies in Australia were used by Australian travellers to justify colonial oversight of the Pacific to protect indigenous people and to reassure themselves of their own national policy of a 'White Australia'. The White Australia policy was a source of pride for many Australians who believed that it protected the nation from an Asian invasion. Historian David Walker characterised Australia as an 'anxious nation' at the turn of the twentieth century, with the imagined geopolitical threat of Asia propelling a 'powerful masculinising and racialising impulse in Australian nationalism' . ${ }^{85}$ Journalist Frank Fox expressed this sentiment in his 1912 travelogue: 'Australia is at once the fortress which the White Race has thinly garrisoned against an Asiatic advance southward, and the most tempting prize to inspire the Asiatic to that advance'. ${ }^{86}$ This racial preoccupation with Asia influenced the travel accounts of the Pacific Islands.

Australian reactions to Japanese migrants in Hawai $i$ were characterised by a disappointment that their expectations of Hawaiian and/or American society were not met, or by a general concern about the growing military threat that Japan posed post-World War I. Japanese migration was most visible in Hawai $i$, though they were spread extensively throughout the Pacific Islands. They were also visible in smaller concentrations in pearling stations along the north Queensland coast, as labourers in New Caledonia, Banaba, Nauru and Queensland (on sugar plantations) and as traders in Micronesia. Their population in Australia was relatively small, numbering only 3,489 in the 1911 census. ${ }^{87}$ This explains why few Australians who travelled to the Pacific were familiar with Japanese culture and why they relied instead on generic stereotypes.

85 David Walker, Anxious Nation: Australia and the Rise of Asia, 1850-1939 (St Lucia: University of Queensland Press, 1999), 5.

86 Fox, Problems of the Pacific, 107.

87 'Japan-Born Community Information Summary', Commonwealth of Australia, www. homeaffairs.gov.au/mca/files/2016-cis-japan.PDF. 
Sustained labour migration from Japan to Hawai'i began from 8 February 1885 , as contract labour for sugar and pineapple plantations. By 1920, the Japanese constituted 43 per cent of Hawai i's population. This numerical dominance was a frequent observation of many Australian travellers who passed through Hawai' $i$. As Anne Rees revealed in her study of Australian female travellers to the US, expectations of an exclusively white and American nation that was similar to Australia were shattered by the racial and cultural hybridity of Hawai' $\mathrm{i}^{88}$ Many Australians represented the Japanese threat as a reproductive one. The notion that Japanese people would 'out-breed' other races was one also applied to Chinese and Indian people in the Pacific. In 1929, George Meudell remarked that they 'breed quicker than flies or rabbits' and, in a patriotic treatise, he argued that the Australian 'doors' of immigration not allow 'inferior, ignorant humans' ${ }^{89}$ Meudell observed that 'the aborigines [indigenous Hawaiians] are decadent and will shortly vanish as a race'. Yet, his concern for the indigenous population of Hawai $i$ was uncommon, as few travellers encountered Islanders during their transit at the port in Honolulu. Rather, the Japanese were perceived as spoiling the Island paradise that many Australians sought, possessing a 'pervasive, acrid smell of Asia' that was 'haunting, persistent, disquieting..$^{90}$

Not all Australian accounts were as damning and vehement in their opposition to Japanese people. Some understood the racial tensions that existed within Hawai' $i$, caused by the population growth and economic prosperity of Japanese residents. Although many Japanese labourers worked on plantations, Australian tourists frequently observed them working at the docks and within the town. In 1925, politician Richard Meagher noted that 'there is an enormous distrust of the Japanese. Rightly or wrongly they get the credit of being at the back of various industrial disturbances'. ${ }^{91}$ Robert McMillan, who visited Hawai' $i$ in 1903 , argued that the Islands were 'just simmering in destructive discontent'. ${ }^{92}$ Others, such as Paul McGuire, predicted a more mixed future race, arguing that ' $\mathrm{He}$ is a Chinese-Japanese-Scandinavian compound with flecks of Polynesian, and he is, I suspect, Pacific Man of to-morrow'. ${ }^{33}$

88 Rees, 'Ellis Island in the Pacific'.

89 Meudell, The Pleasant Career of a Spendthrift, 144.

90 Fox, Oceania, 9.

91 Richard Denis Meagher, American Impressions (Sydney: Gordon \& Gotch, 1925), 8.

92 McMillan, There and Back, 358. He further added that 'the little brown man is absolutely wicked'.

93 McGuire, Westward the Course, 44. 
The establishment of Pan-Pacific conferences in the 1930s, many of which were based in Hawai' $i$, also encouraged cross-cultural encounters and sympathetic understanding to a degree. ${ }^{94}$

The 1930s were marked by fears of war, colouring Australian attitudes to Japanese residents in Hawai' $i$. When journalist Eric Baume visited Hawai' $i$ in 1937, he proudly stated that Australia did not have 'any Japanese problem because we took good care we would not'. ${ }^{55}$ Although potential enemies were vaguely located in Asia in the 1920s and 1930s, by the end of the decade, the military strength of the Japanese attracted the most concern. Their skill had already been proven in the Russo-Japanese War of 1904-1905, and their acquisition of Micronesian Islands after World War I was well known among Australians. This was evident in certain travel accounts, such as those by Villiers, who avoided the Caroline Islands for fear of being called a spy, and Marshall, who, although expressing anticolonial sentiments, argued for Australian settlement in New Guinea to protect it from Japanese hands. ${ }^{96}$ Books with titles such as Pacific Peril contributed to a sense of panic in Australia-which was reflected in comments made by travellers like Thomas McKay, who explicitly warned his readers that 'Australians may wake up some fine morning to find Japan installed as their next-door neighbour'. ${ }^{97}$

The Chinese influence in the Pacific Islands was also frequently noted by Australian travellers. However, the Chinese were more often identified with economic prosperity than the Japanese. Chinese, 'Chinamen' or 'Orientals' were described in various locations: 'John Chinaman' fishing in Hawai' $i$, eating at 'Sam Doos' restaurant in the Solomon Islands, walking through 'Chinatown' in Suva, working as a trader in the Gilbert Islands and with an 'Asiatic' crew onboard ships. ${ }^{98}$ If they were represented pictorially, they would be decoratively adorned and usually in masculine form, with exaggerated or distorted body shapes and facial features. Australians were

94 Janet Mitchell, Spoils of Opportunity: An Autobiography (New York: Dutton, 1939); Paisley, Glamour in the Pacific.

95 Baume, I Lived These Years, 167.

96 Villiers, Cruise of the Conrad, 133; Jock Marshall, The Men and Birds of Paradise: Journeys through Equatorial New Guinea (London: William Heinemann, 1938), 131. See also Ernest George Marks, Pacific Peril, or, Menace of Japan's Mandated Islands (Sydney: Wynyard Book Arcade, 1933).

97 Marks, Pacific Peril; McKay, Seeing the World Twice, xv.

98 James Park Thomson, Round the World (Brisbane: Outridge Printing Co., 1904), 8; Villiers, Cruise of the Conrad, 172; Allan, Homeward Bound, 24; Rosa Angela Kirkcaldie, In Gray and Scarlet (Melbourne: Alexander McCubbin, 1922), 30; Osborne, Through the Atolls of the Line; Thomas, Cannibals and Convicts, 49. 
also familiar with the Chinese people since their immigration to the New South Wales and Victorian goldfields in the 1850s. They were the largest ethnic minority in Australia, other than Aboriginal Australians. By the late 1870 s, their population peaked to $38,553 .{ }^{99}$ Their wide geographical distribution encouraged fears of a racial overpowering of the Pacific Islands and Australia.

The Chinese had a long history of contact with the Pacific Islands, first as carpenters and cooks who travelled with sandalwood traders in the midnineteenth century, then as traders and indentured labourers in French Polynesia, New Guinea, Samoa and the Gilbert Islands. Their numbers remained relatively small until the 1930s, but they were noted for their economic enterprise (as cooks and store owners), incurring the enmity of Europeans because they were frugal, willing to work long hours, lived more simply and could undersell European traders. ${ }^{100}$ These concerns were evident in the 1932 article 'Chinese Problem in the South Seas', in the Pacific Islands Monthly. ${ }^{101}$ The Chinese were also vocal and active in defending their rights - this was demonstrated when the Chinese consul-general in Australia sent a representative to the Solomon Islands to challenge discriminatory policies, and in the New Hebrides, when Chinese residents formed a 'Chinese club' in 1932 in response to antiChinese sentiment. ${ }^{102}$

Australians criticised the Chinese in particular because of their dominance in Tahiti. This was due to the highly romanticised Polynesian ideal, the large population of Chinese people residing there, their relative economic prosperity and the low visibility of other Asian cultures. ${ }^{103}$ Initially, Australian tourists resented the Chinese for spoiling the primitive ideal that they expected in Tahiti, though this was only one of many corrupting influences to be blamed. More threatening to Australians was the potential for interbreeding, with the Chinese having intermarried freely with Polynesians in Tahiti from the late nineteenth century to the extent that Powell wrote in 1942: 'The Chinese ... are in Tahiti absorbed'. ${ }^{104}$

99 Woollacott, To Try Her Fortune in London, 173.

100 William E Willmott, A History of the Chinese Communities in Eastern Melanesia: Solomon Islands, Vanuatu, New Caledonia (Christchurch: Macmillan Brown Centre for Pacific Studies, University of Canterbury, 2005), 13.

101 'Chinese Problem in the South Seas', Pacific Islands Monthly 3, no. 5 (December 1932): 33

102 Willmott, A History of the Chinese Communities, 16, 39.

103 Newbury, Tahiti Nui, 263-71.

104 Powell, A South Sea Diary, 24. 
This reflected a wider concern about the fragility of the Pacific Islander races and the proliferation of 'half-breeds of various colours'. ${ }^{105}$ Some, like Powell, believed that 'the Chinese and the Europeans here have saved the Tahitian race from its threatened extinction', ${ }^{106}$ but this view belonged to a minority. Concerns about interbreeding were not as prevalent in Melanesia, where William E Willmott demonstrated that, although most Chinese migrants were single men, intermarriage was rare. ${ }^{107}$

Much more common and widespread was a fear of Chinese dominance, both in the Pacific Islands and in Australia. This reflected the broader concern of an Asian 'invasion' in the region. This was suggested by travellers like Safroni-Middleton, who indiscriminately blended racial characteristics to imagine a hybrid race of 'several stealthy-footed followers of Mohammed, a kind of mongrel, half-caste Chinese-Indian'. ${ }^{108}$ Although these exaggerated and blended stereotypes were common, other travellers experienced genuine surprise and ambivalence, as tourist Alfred Hill's account in 1927 demonstrated:

$\mathrm{He}$ is quiet, law-abiding, patient and persevering, biding his time and opportunity and then seizing it with both hands and coming out on top. This is the history of almost every island in the Pacific, and gives thought to those who consider the ultimate destiny of the lands bordering it. It comes as rather a rude shock to an Australian to find that the Chinese are treated by the whites and natives with the same deference as is extended to the white man. They also travel first class on the steamers, dine in the saloon, and frequent the smokerooms and lounges, also best seats in the pictures. At first one feels a repugnance, but, finding it is the accepted custom, one gradually sees the sense, and the Chinaman is treated an equal, which, in most cases he is, if not a superior. ${ }^{109}$

As Hill's comments suggest, the clearest danger that Australians perceived was the Chinese work ethic and their subsequent economic prosperity. Australians frequently identified Chinese people as business owners throughout the region, describing them as hardworking and shrewd, yet cunning and undermining. In Nossiter's perspective, the Chinese took advantage of the weak:

105 Irwin and Goff, No Longer Innocent, 90.

106 Powell, A South Sea Diary, 24.

107 Willmott, A History of the Chinese Communities, 17.

108 Safroni-Middleton, Wine-Dark Seas and Tropic Skies, 29.

109 Hill, A Cruise among Former Cannibal Islands, 43-4. 
The Chinaman works hard wherever he goes, keeps his shop open for trade day and night and quickly becomes the shopkeeper of a town or village. They undersell the other traders, whom they put out of business ... In the old civilized countries as India, Ceylon, Egypt and Arabia, they are not to be found in any numbers, neither does one come across them in Europe. It seems to me the Chinaman selects the newer civilisation where the people are unsophisticated and careless. ${ }^{110}$

Many travellers commented on 'Chinese trade robbers', who were considered corrupt and amoral, or Chinese storekeepers, who would manipulate or trick customers. However, this resentment was tempered by the view that the Chinese were necessary in the Pacific because they were racially superior to the Islanders, and thus a more capable and reliable labour force. After leaving Circular Quay for the Pacific Islands in 1878, Thomas noted many Chinese people ashore and remarked: 'He, like the poor, is always with us; and, like poverty, we look upon him as a disagreeable necessity'. ${ }^{111}$

This ambiguous attitude was also directed towards Indians in the Pacific Islands, particularly the large population living in Fiji. The nation's proximity to Australia and its close relationship with Australian business, trade, Christian missions and tourism signified that race was an issue that Australian travel writers in the Pacific most frequently associated with Fiji. Fijis location on the border of Melanesia and Polynesia also generated uncertainty among Australians who were unsure how to regard people who were physically darker, yet who shared similarities in kinship systems, language and traditions with Polynesia, as well as having British colonial affinities. United by their shared British colonial heritage, Australians approached Fiji (and its Indian population) with greater familiarity and confidence to pronounce judgement on the merits and faults of its people and its colonial masters.

Henley noted this colonial familiarity when he wrote about Fiji in 1926: 'The Fijians regard Australia as the big brother, and ask for a brotherly consideration in trade matters'. ${ }^{112}$ Trade and business underpinned Australian engagement with the colony, and it promoted the exchange of people as well as goods. This British imperial connection even prompted

110 Nossiter, Southward Ho!, 152.

111 Thomas, Cannibals and Convicts, 49.

112 Henley, Fiji - The Land of Promise, 58. 
some people, like JS Griffiths, to argue for Australian annexation of Fiji: 'More than two-thirds of the total trade of Fiji is with Australia, and it is largely the sons of Australia who carry on the work in the islands as overseers or clerks'. ${ }^{113}$ Crucial to Fiji's economic success was Indian indentured labour, which had been employed from 1879 to provide a labour force that was considered more reliable than Fijian and other Pacific Islander labourers (as well as ensuring the protection of the indigenous population). By the time that indentured labour immigration ceased in 1916, over 60,000 Indians had immigrated to Fiji. ${ }^{114}$ Despite their numerical dominance, Indians drew little, if any, comment from Australian travellers. When they did, the observations were overwhelmingly negative, repeating the commonly held belief that Indians were 'beasts of burden' who served a primarily commercial purpose. ${ }^{15}$

Encounters with Indians in Fiji were unsurprising to Australian travellers, who were knowledgeable about the indentured labour trade and familiar with Indians living in Australia. The British Empire network had facilitated the exchange of people, goods and ideas between India and Australia since the early nineteenth century. Suzanne Rickard highlighted the migration of Indian seamen, servants, convicts and traders to Australia. ${ }^{116}$ They were followed by an influx of Indian indentured labour that New South Wales pastoralists employed in the 1830s and 1840s, as well as camel handlers and traders from the north-west provinces of India from the 1860s to the 1890 s. ${ }^{117}$ Indians were also visible on cruise ships that travelled to and from Australia; they were preferred as servants in the saloon and on deck, as opposed to other workers who were confined below to the engine

113 JS Griffiths, 'Fiji: The Eastern Outpost of Australia', The Lone Hand (April 1912): 508.

114 See Kenneth Lowell Oliver Gillion, Fijis Indian Migrants: A History to the End of Indenture in 1920 (Melbourne: Oxford University Press, 1962), 76; Brij V Lal, Chalo Jahaji: On a Journey through Indenture in Fiji (Canberra: ANU E Press, 2012), 69, 138, doi.org/10.22459/CJ.12.2012.

115 Gillion, Fijis Indian Migrants, 18.

116 Suzanne Rickard, 'Lifelines from Calcutta', in India, China, Australia: Trade and Society 17881850, ed. James Broadbent, Suzanne Rickard and Margaret Steven (Glebe: Historic Houses Trust of NSW, 2003), 66, 71, 75, 82.

117 Christine Stevens, Tin Mosques and Ghantowns: A History of Afghan Camel Drivers in Australia (Melbourne: Oxford University Press, 1989), 26. For further discussion, see Michael J Cigler, The Afghans in Australia (Melbourne: AE Press, 1986); Pamela Rajkowski, In the Tracks of the Camelmen (North Ryde: Angus \& Robertson, 1987); Peter Scriver, 'Mosques, Ghantowns and Cameleers in the Settlement History of Colonial Australia', Fabrications: The Journal of the Society of Architectural Historians, Australia and New Zealand 13, no. 2 (2004): 19-41, doi.org/10.1080/10331867.2004.105 25182; Heather Goodall, Devleena Ghosh and Lindi R Todd, 'Jumping Ship-Skirting Empire: Indians, Aborigines and Australians across the Indian Ocean', Transforming Cultures eJournal 3, no. 1 (2008): 44-74, doi.org/10.5130/tfc.v3i1.674. 
rooms. ${ }^{118}$ When the Australian colonies federated in 1901, the number of Indians was estimated at 7,637. This number dropped to 3,698 by 1911 due to the Immigration Restriction Act (1901), which overlooked their status as British subjects and classified Indians as 'natives of Asia'. ${ }^{119}$ Their controlled mobility starkly contrasted the unrestricted movement of Australians to India, many of whom were missionaries.

This discrimination was evident in Australian representations of Indians, which emphasised their role as subservient workers. This image was prompted by the jobs in which most Indians were employed, which encouraged a stereotype of Indians as being docile, compliant and hardy. ${ }^{120}$ The terms 'lascars' (sailors), 'Afghans' (cameleers), 'hawkers' (traders) and 'coolies' (unskilled labourers) not only became synonymous with Indians, but they also became racialised categories that relegated the Indian to an inferior status to white Australians. Despite this assumed inferiority, Australians expressed their concern about the ascendancy of Indians, most commonly in objection to the dominance of lascars on ships. ${ }^{121}$ Like the Chinese and Japanese, Indians were part of the general notion of an Asian menace that served to reinforce a nationalist ideology of racial purity and control in Australia. Apart from lascars, Indian migrants living in Australia did not constitute a large enough group to prompt the same hostility from Australians that was reserved for Fiji.

After arriving in Suva, Australians' first impressions reveal an immediate awareness of the multi-racial nature of the Fijian community. A 'medley of races' was a phrase commonly used to describe Suva wharf, a place at which the prevalence of Chinese and Indians was often noted. During his gold prospecting in the early 1930s, Fraser recalled:

The streets of Suva were busy, and the medley of people in their distinctive costumes presented a lively and colourful picture ... But by far the greatest part of the population seemed to be made up of Indians, Fijians, and Chinese, in about that order numerically. Every waiter and taxi-driver we saw was an Indian, and we

118 Goodall, Ghosh and Todd, 'Jumping Ship-Skirting Empire', 54.

119 Margaret Allen, "Innocents Abroad" and "Prohibited Immigrants": Australians in India and Indians in Australia 1890-1910', in Connected Worlds: History in Transnational Perspective, ed. Ann Curthoys and Marilyn Lake (Canberra: ANU E Press, 2006), 120, doi.org/10.22459/CW.03.2006.

120 Ravi Ahuja, in Goodall, Ghosh and Todd, 'Jumping Ship-Skirting Empire', 47; Scriver, 'Mosques, Ghantowns and Cameleers', 26.

121 Goodall, Ghosh and Todd, 'Jumping Ship-Skirting Empire', 56. 
learned that the most skilled work, such as that of carpenters and mechanics, was in their slim dark hands. They usually looked much the same as the Hindu hawkers of Australia. ${ }^{122}$

It is evident from Fraser's statement that Indians were clearly visible in Suva by the 1930s. This was not the case in the 1880s and 1890s, when the Indian population was small, isolated and dispersed across Fiji. The difficulty of access to other districts on the main island of Viti Levu explains the absence of Indians from Australian travel accounts during this time. However, by the 1910s, Australian visits were more frequent, more prolonged and more probing. Consequently, visitors wrote of short, glancing encounters with Indian taxi drivers, Indian shopkeepers, Indian housekeepers and Indian waiters. In 1924, Meagher visited the Grand Pacific Hotel and observed:

The attendants, all Hindoos in immaculate white garb with coloured sashes, prove excellent waiters. Nearly all the motor-car drivers are Hindoos, the one I employed to drive around the island being particularly intelligent. The number of Hindoos in the place is astounding. ${ }^{123}$

It was also possible to visit the sugar mills of CSR, which offered a passenger service on its commercial line. Harriet Ponder was an experienced traveller who fondly remembered travelling on the train in 1924:

You can travel (free) over the hundred miles of two-foot-gauge railway built by the Colonial Sugar Refining Company to serve the coastal sugar districts of Viti Levu ... for a trip on this train provides a miniature pageant of island life that it would not be easy to equal ... At every plantation at which the train stops to hand out the week's pay, the stranger feels inclined to rub his eyes and wonder whether he is travelling in India by mistake. ${ }^{124}$

The observations of Indians when they were noticed were casual, essentialist and negative. Few Australian visitors had sustained contact with Indians in Fiji. Instead, they drew on the stereotypes that were used in previous European literature, which reinforced an anti-Indian prejudice. This image was enhanced by comparisons to the indigenous Fijian population, who were romanticised as primitive and innocent and who were framed within a discourse of protectionism in response to their perceived depopulation.

122 Fraser, Gold Dish and Kava Bowl, 45.

123 Meagher, American Impressions, 6.

124 Ponder, An Idler in the Islands, 18, 56, 61. 
Australian travellers seeking the exotic Islander were uninterested in Indian culture or traditions, and rarely described Indian houses, clothes, food or cultural traditions. Indians were considered a foreign intrusion in the Pacific Islands, their population described by Robert Brummitt as 'the Indian Invasion' in 1914. ${ }^{125}$ When Indian women were described, it was to note the common practice of wearing jewellery while working on the plantations. In contrast to their 'innocent' Fijian neighbours, Indians were represented as treacherous and cunning, waiting to take advantage of gullible tourists or naive overseers. These ideas were fuelled by speculative reports in the local press and planters' fears of Indian uprisings, especially in the 1900 s. ${ }^{126}$ Stock made dismal and degrading remarks about Indians at work in 1913:

Here were the sullen, the cunning, the murderous, the fawning and the banal ... culled from the dregs of central India ... The islander is a child throughout life, the coolie, for the most part, a snake. ${ }^{127}$

As Stock's comment suggests, the threat was emphasised by comparing Indians to the innocent Fijians. It also highlights a commonly held belief that Indians living in Fiji were outcasts who were 'crowded out' from their 'old land'. ${ }^{128}$

Portrayals of Indians living in Fiji as outcasts conflicted with conventional representations of India in Australia and the broader British Empire. As Walker revealed, Indians were admired for their ancient cultural traditions, with Australian travellers to India emphasising the nation's 'antiquity and spiritual wealth'. ${ }^{129}$ Racial notions of Aryanism proposed that Europeans shared a common Aryan heritage with Indians and that Asia (specifically central Asia/north India) was identified as the cradle of humanity. Tony Ballantyne argued that this racial connection was amplified by the colonial exchange between India and the rest of the Empire, not only of goods and people but also of ideas. ${ }^{130}$ Travellers to India, like GT Garratt, admired the cultural legacy of the subcontinent, Garratt remarked in 1937 that:

125 Brummitt, $A$ Winter Holiday in Fiji, 132.

126 Gillion, Fijis Indian Migrants, 156-7.

127 Stock, The Confessions of a Tenderfoot, 174, 176.

128 Fraser, Gold Dish and Kava Bowl, 237.

129 Walker, Anxious Nation, 19. See also Allen, "Innocents Abroad" and "Prohibited Immigrants", 112.

130 Ballantyne, Webs of Empire, 30-3. Ballantyne's description of Aryanism in New Zealand can be applied to the Australian context. 
More and more, however, we are beginning to realize the innumerable contacts, throughout the course of history, between East and West, and their mutual indebtedness in language, literature, art and philosophy. ${ }^{131}$

In comparison, Indians in Fiji did not receive the same treatment, attracting mainly hostile and disparaging judgements.

The strong religious and cultural traditions that Indian migrants brought with them to Fiji made the conversion efforts of European missionaries difficult. Reverend Burton noted the difficulty of converting Indians to Christianity in 1914 (a task that had not been undertaken by missionaries until 1892):

The results, statistically, are small, and it is to be feared the impression made upon the population is only slight ... So far, the Hindu and Muhammadan influences of the home and parents have been stronger than the Christian influence in the school. ${ }^{132}$

Consequently, Indians were represented by missionaries more negatively. Missionaries emphasised their stubbornness and heathenism and compared them to indigenous Fijians, who were often described as the model Pacific Islander because they had been Christianised. ${ }^{133}$ These descriptions filtered into Australian travel accounts, like those of Methodist doctor Brummitt, who concluded that Indians were 'often very ignorant and superstitious ... subject to the most violent passions, which often find expression in violent deed ... under the influence of jealousy or of revenge'. ${ }^{134}$ Safroni-Middleton's comparison emphasised the fragility of Fijians, arguing that the Eastern religions that were introduced threatened traditional religious beliefs:

The Indian sadhu (saint) sits by the line of dens and stores under the palms; he looks like some carved holy image as he stares with bright, unblinking eyes. The natives' wooden idols have long since been smashed, or have rotted away and that living idol of the East is one from many cargoes that have arrived to take the place of the old deaf South Sea idols. The new idols are real ... the deaf, dumb wooden gods of heathen times were sanctified compared with these new immigrant idols that breathe! ${ }^{135}$

131 HG Rawlinson, 'Indian in European Literature and Thought', in The Legacy of India, ed. GT Garratt (Oxford: The Clarendon Press, 1937), 37.

132 Burton, The Call of the Pacific, 110, 112.

133 Paton, Thirty Years with South Sea Cannibals, 108.

134 Brummitt, A Winter Holiday in Fiji, 138.

135 Safroni-Middleton, A Vagabond's Odyssey, 56. 
The perpetuation of negative Indian stereotypes was closely connected to Indians' association with hard labour and industry. They were often overlooked because they did not match the exotic imaginings of a carefree island way of life, and the reality of life while working on sugar plantations and mills was not appealing or picturesque. Burton was one of the earliest Australians to detail the terrible living conditions of indentured labourers:

The coolie 'lines' (as they are called) are long rows of tarred, wooden buildings, which might be taken as the very apotheosis of architectural ugliness ... In each of these miserable kennels three men, or one family, have to eat and sleep ... Vice, wickedness, and abjectness abound. Personal filth is ever in evidence, and life seems to have turned rancid. ${ }^{136}$

Framed within a discourse of labour and commerce, the Indian work ethic reinforced the undisputed assumption of the Fijian's unwillingness to work. ${ }^{137}$ Like most Europeans, Henley considered idleness a natural trait of the Fijian race, and attributed it to the natural abundance of the Islands and an 'ingrained conception of communal rights'. ${ }^{138}$ Journalist Charles Edwin Woodrow Bean commented in 1909 that, 'The Fijian is a gentleman, and lives in comfort ... [he] is there for ornament, not for use'. ${ }^{139}$ Similarly, Indians were believed to have a natural affinity for hard labour and to 'possess powers of endurance which make them suitable plantation workers'. ${ }^{140}$

With this potential came a warning regarding their supposed tendency for violence and the need for strict discipline-a stereotype that originated from planters' fears of Indian uprisings. Fears of violence may also have been stoked by anti-colonial protests in India during the 1920s and 1930s. ${ }^{141}$ It was a common assumption in Australian travel writing that Indians committed many murders, often of their overseers or of Indian women. For example, Bean wrote:

136 Burton, The Call of the Pacific, 107.

137 Lal, Chalo Jahaji, 69.

138 Henley, Fiji-The Land of Promise, 56.

139 Bean, With the Flagship of the South, 57.

140 Burton, The Call of the Pacific, 104.

141 Lal, Chalo Jahaji, 174; John Dunham Kelly, A Politics of Virtue: Hinduism, Sexuality, and Countercolonial Discourse in Fiji (Chicago: University of Chicago Press, 1991), 142. 
The strange part of it is that, though he seemed so spiritless, he had been committing nearly all the murders in the island ... the Indian murders simply because he is passionately moral. ${ }^{142}$

Realistically, Australian travellers did not encounter violent Indians. Instead, contact was usually momentary and superficial, with Indians being described as serious and unfriendly. This may have been partly due to the general European prejudice towards Indians and the lack of sustained engagement with them. However, it also resonates with Brij V Lal's summary of Indian responses to overt prejudice and oppression, particularly in the plantations, whereby active non-resistance, thus, became a strategy for survival'. ${ }^{143}$ The mistreatment of Indian indentured labourers, often under the supervision of the CSR or at the hands of Australian overseers, contributed to an Indian distrust of white men.

Although most Australian travel writing overlooked Indians in Fiji, there were some perceptive travellers who described the Indian population in more generous terms. Unlike the 1880s and 1890s, when little information about Indian indentured labour was available to British and Australian audiences, Australian interest in the indenture issue increased during the 1910s and 1920s. The decline of the Fijian population and the growth of the Indians became a major concern for the British administration, which was a concern echoed in other travel accounts. Burton was a particularly influential Australian Methodist who highlighted the 'dehumanising' indenture system. Australians were well informed of the nationalist movement in India at the time, and the plight of Indo-Fijians became part of this international political discourse. Indians were active in organising themselves in Fiji and in forming connections with the Indian nationalist movement abroad, raising the profile of their cause. Indian barristers, missionaries, teachers and lawyers were sent to Fiji under the sponsorship of Indian organisations to document the circumstances of indenture and support Indian labourers who were persecuted by colonial masters. ${ }^{144}$ At home, some Australians offered sympathy and support. Gillion offered an example of 46 women's organisations from Australia and New Zealand who sent a delegate to Fiji to investigate indenture conditions in $1919 .{ }^{145}$ Within the body of Australian travel writing are examples of this growing

142 Bean, With the Flagship of the South, 58.

143 Lal, Chalo Jahaji, 168.

144 Kelly, A Politics of Virtue, 115, 142.

145 Gillion, Fijis Indian Migrants, 187. 
Australian concern for Indians' welfare and a softening of racialist attitudes towards them. Brummitt echoed Burton's concerns that indenture was dehumanising in 1914; Henley's account argued for a better organised and regulated administration in 1926; and, in 1935, Bendigo miner WJ Stephens demanded that the British government make reparations to indentured labourers. ${ }^{146}$

Whether encountering Indians, Chinese, Japanese or other 'Asiatic' types, Australian travellers were generally surprised to find racial and cultural hybridity in the Pacific Islands. Their experiences of travel tested their understanding of race and human difference, forcing them to consider the merits of maintaining a racially pure, white Australia. Race was an integral part of Australian travel writing, informing Australians throughout their Pacific journeys. Travel literature and science in the Pacific have been historically intertwined; travellers adopted scientific practices and language with ease, yet applied scientific ideas indiscriminately and ambiguously. The most significant assumption that Australians carried with them was that race was an uncontested category, a rigid hierarchy in which Pacific Islanders were static, timeless and locked into a particular position. Their observations of disease and the tropical environment, of depopulation and of other foreigners were informed by this assumption, one that had hardened over time from the 1880 s to the 1940s.

Although many travel accounts repeated these racialist assumptions and stereotypes, some Australians struggled to reconcile strict racial categories with the multi-racial reality of the Pacific Islands. In 1934, in the New Hebrides, zoologist Alan John Marshall and his British companion, Tom, ridiculed a pamphlet that was given to him by a customs official titled Talking Points of Australia:

'Do you realise, Tom,' I held forth, 'that my country is the healthiest in the world; that my city, Sydney is the second greatest in the British Empire? ... [and] you should certainly know that our White Australia policy ensures that we shall have no "colour problem" ... Again, the booklet says (and it must be right) that we are rapidly developing into a distinctive race-tall, strong and athletic; proud of our freedom and progress, yet loyal, dear Tom, and living up to the best traditions of justice, humanity and hospitality!' ${ }^{147}$

146 Henley, Fiji-The Land of Promise; Brummitt, $A$ Winter Holiday in Fiji; Stephens, Samoan Holidays. 147 Marshall, The Black Musketeers, 168. 
In reply, Tom remarked, 'I haven't noticed any of those traits in you'. Such criticisms revealed the flaws in Australia's efforts to preserve health and race at home and abroad. The limited number of these accounts means that it is difficult to identify whether travellers like Marshall were exceptional, or whether they represent a broader trend in Australia in the 1920s and 1930s. This period was a time of great social and economic change in Australia after World War I, and the acquisition of new mandates in the Pacific encouraged a more internationalist outlook among Australians. Anderson's history of Australian medical theory and practice suggested that the interwar period was a significant time when conventional knowledge and racial policies were contested and negotiated within medical establishments. In the same way that the practical experience of doctors contributed to changes in medical theory, the experience of Australian travellers who witnessed the growth of European and Asian populations in the tropical Pacific began to undermine popular views at home of a static or hostile neighbouring region. 
This text is taken from Australian Travellers in the South Seas, by Nicholas Halter, published 2021 by ANU Press, The Australian National University, Canberra, Australia.

doi.org/10.22459/ATSS.2021.07 